\title{
Problem-Based Learning in an Online Reading Course to Stimulate Critical Thinking Skills
}

\author{
*Dewi Suriyani Djamdjuri ${ }^{1} \&$ Maeleni $^{2}$ \\ ${ }^{1,2}$ Universitas Ibn Khaldun Bogor, Indonesia \\ *email: dewi.suriyani@uika-bogor.ac.id
}

\begin{abstract}
This study aims to investigate the implementation of PBL to stimulate students' critical thinking skills in online reading courses based on previous studies. A descriptive approach qualitative research was employed using interviews and document analysis as data collection with one lecturer and six students in the third semester of the English Department at one of the universities in Bogor. The findings revealed that the implementation of PBL to stimulate critical thinking skills in online reading courses had some positive impacts and some obstacles. The positive impacts which were found, PBL is quite appropriate to promote students' critical thinking skills and solve problems using their critical thinking skills. Furthermore, students could be more focused on studying and students could learn to understand and analyze, not just memorizing. The findings of obstacles reveal that the lecturer brings about such obstacles as the difficulty of determining good problems to stimulate critical thinking skills, and it is not easy to position himself as a facilitator, guiding, exploring deeper understanding, and supporting students' initiative. The obstacles for the students reveal a lack of enthusiasm for solving problems and a lack of confidence in expressing opinions.
\end{abstract}

Keywords: Problem Based Learning, Online Reading Course, Critical Thinking Skills.

\begin{abstract}
Abstrak: Penelitian ini bertujuan untuk menyelidiki penerapan PBL untuk merangsang keterampilan berpikir kritis siswa dalam mata kuliah reading secara online berdasarkan penelitian sebelumnya. Penelitian kualitatif dengan pendekatan deskriptif menggunakan wawancara dan analisis dokumen sebagai instrumen dengan satu dosen dan enam mahasiswa semester tiga Jurusan Bahasa Inggris di salah satu Universitas di Bogor. Hasil penelitian menunjukkan bahwa penerapan PBL untuk merangsang keterampilan berpikir kritis dalam mata kuliah reading secara online memiliki beberapa dampak positif dan beberapa hambatan. Dampak positif ditemukan bahwa PBL cukup tepat untuk meningkatkan kemampuan berpikir kritis siswa dan memecahkan masalah dengan menggunakan pemikiran kritisnya, siswa dapat belajar lebih fokus, siswa belajar memahami dan menganalisis bukan hanya menghafal. Temuan kendala mengungkapkan bahwa dosen menimbulkan kendala seperti kesulitan menentukan masalah yang baik untuk merangsang kemampuan berpikir kritis, tidak mudah memposisikan diri sebagai fasilitator, membimbing, menggali pemahaman yang lebih dalam, dan mendukung inisiatif mahasiswa. Kendala yang dialami siswa antara lain kurangnya semangat dalam memecahkan masalah dan masih kurang percaya diri dalam mengemukakan pendapat.
\end{abstract}

Kata Kunci: Pembelajaran Berbasis Masalah, Mata Kuliah Reading Online, Keterampilan Berpikir Kritis 


\section{INTRODUCTION}

The issue of Critical Thinking in the model of Problem-Based Learning (PBL) has received considerable critical attention.Problem-Based Learning is a pedagogical model that engages learners in a complex problem-solving activity in which the problem drives all learning and no formal prior knowledge is assumed in the content area for which the problem is intended(Dabbagh, 2019). Furthermore, Dabbagh (2019) suggests that Problem-based learning (PBL) has been shown to foster the development and improvement of critical thinking skills such as problem solving, analytic thinking, decision making, reasoning, argumentation, interpretation, synthesis, evaluation, collaboration, communication, and self-directed learning.

There are many factors affect the success of the learning activity so that it is necessary to understand all the factors that exist so that the education that is summarized in student learning outcomes can be achieved in accordance with which are expected. Learning difficulties can come from students but also caused by factors in the learning environment (Suherni, 2021). Furthermore, Suherni (2021) also argue that students' ability to understanding the lesson, students' persistence and the opportunity provided to study the specified scope of material are also important factors affect learning outcomes and the teacher's methods to teach reading are important factors that may affect the students' ability in reading skill. There are some kinds of methods that can be applied by the English teacher to develop his/her students' ability in reading skill. One of the methods that can be used is Problem-Based Learning (PBL).

A considerable amount of literature has been published on the issue of Critical thinking in the model of Problem-Based Learning. PBL supports students' thinking skills to a higher level, especially their critical thinking skills(Ragilia, 2018). The Council of Writing Program Administrators (2014) define that "Critical thinking is the ability to analyze, synthesize, interpret, and evaluate ideas, information, situations, and texts." Further, Dabbagh (2019) suggests that critical thinking skills have consistently made the cut as desirable higher education student learning outcomes when government and consumer agencies call for education reforms that will ready graduates for professional and societal 
responsibilities. One way to foster critical thinking in a variety of content areas is through problem-based learning. Problem-based learning has been shown by some researchers to support development of students' critical thinking.

In addition,to operationalize education associated with sustainability, teaching approaches must focus on elements relating to the processes of learning, rather than the accumulation of knowledge to develop graduates with capabilities to improvise, adapt, innovate, and be creative(Thomas, 2010). Skills such as interdisciplinary thinking, problem solving, team working, and critical thinking are often mentioned. These skills are encompassed by the pedagogy of ProblemBased Learning (PBL), which provides students with opportunities to learn to think, specifically "how to think" rather than "what to think," and potentially within the framework of sustainability. Sharma (as cited in Steinemann (2003) comments on the context for PBL, Problem-based learning emphasizes learning by doing. It also provides a motivating context for learning. Students are given a real-world problem similar to those they would face as professionals. They take ownership of the problem, and the problemsolving process (p. 218).

Research on PBL and its effectiveness in fostering critical thinking skills spans decades and its scope encompasses multiple disciplines and contexts. (Kumar, 2017) investigated whether PBL in an intermediate composition course at a 2-year college supported the development of student critical thinking skills in English Composition Course. The findings demonstrates that PBL has a significant effect on fostering critical thinking skills such as problem solving, communication, collaboration, self-directed learning, reflection, clinical reasoning, analytic thinking, logical thinking, decision making, and conceptual change among others.

Regarding second and foreign language education, Lin (2017) conducted a survey investigating the students' perceptions of PBL in a university in Taiwan and indicated that research has been conducted to examine integrated the PBL pedagogy into a web-based English reading course. Several reports have shown that the finding suggests that the PBL approach foster the participants' English reading. In addition, the findings suggest that $\mathrm{PBL}$ could cultivate their active 
learning, help them to synthesize the data, help them to distinguish main ideas and details, and also help them improve their critical thinking skills.

In Indonesian context of Higher Education, there are several studies examine the implementation of Problem Based learning to improve Critical Thinking Skills. One of the studies are from Fakhriyah (2014) conducted a research on PBL with the title Implementation of Problem Based Learning in Efforts Develop Student's Critical Thinking Abilities. Second, Sulaiman \& Azizah (2020) conducted a research with the title Problem-Based Learning to Improve Critical Thinking Ability In Indonesia: A Systematic Literature Review. And third, Malahayati (2018) identified the Cooperative Integrated Reading and Composition (CIRC) learning model combined with Problem Based Learning (PBL) to improve problem solving skills and critical thinking skills of students.

The importance of this research is to determine the effectiveness of using a problem-based learning model to stimulate students' critical thinking skills in online reading course. To understand the effectiveness of PBL, the researchers examined whether PBL could be effectively foster university students' critical thinking skills and English Reading ability.It is necessary to know a perception from the lecturer and the students and to find out how to promote critical thinking skills through the implementation of problem based learning and to know which activities can promote students' critical thinking skills towards the implementation of problem based learning in an online reading course.

\section{METHOD}

This research was conducted using a descriptive qualitative approach. According to Gay et al (2012, p.7), "Qualitative research is the collection, analysis, and interpretation of comprehensive narrative and visual (non-numeric) data to gain insights into a particular phenomenon of interest." Furthermore, qualitative descriptive is a study that is described in words, used to analyse various phenomena that occur in individuals, groups, or communities. Nassaji (2015) stated that "The goal of descriptive research is to describe a phenomenon and its characteristics." Therefore, the researchers used a descriptive qualitative approach to collect the data based on the experience of the participants, especially for the English students in an online reading course. In this study, the writers 
conducted research at one university in Bogor. There were 30 students in the third semester of academic year 2020/2021 of the English Department, but only 6 students were taken as the respondents. In addition, 1 lecturer was also as participant. The data was gained through a set of interviews about students' perceptions of the implementation of the problem-based learning method in an online reading course, and document analysis to support the findings.

\section{RESULTS AND DISCUSSION}

The present study was designed to examine the implementation of Problem-Based Learning in an online reading course to simulate critical thinking skills. Drawing on interview guidelines and document analysis data, four emergent themes are presented along with supporting data: (1) the implementation of Problem-Based Learning in online learning and teaching in reading course during covid-19 pandemic, (2) critical thinking skills in the implementation of Problem-Based Learning in online reading course, (3) activities in online reading course toward the implementation of Problem-Based Learning to stimulate critical thinking skills, and (4) the design of syllabus and learning materials used in reading course in the implementation of Problem-Based Learning. The explanation of each parts will be discussed as follows.

\section{The Implementation of Probelm-Based Learning in an Online Learning and Teaching in Reading Course During Covid-19 Pandemic}

The first theme emerging from the interview data is the implementation of Problem-Based Learning in an online learning and teaching in reading course during covid-19 pandemic. This finding theme emerged from the interview data analysis to portray

Table.1 Sample data analysis.

\begin{tabular}{clc}
\hline Emergent themes & \multicolumn{1}{c}{ Data } & Sources \\
\hline Implementation of & I think it's the same. Even though & Semi-structured \\
Problem-Based & studying via online, the material is & interview \\
Learning in an online & still conveyed well and with the & \\
reading course to & implementation of PBL in my \\
simulate critical & opinion the lecturer's strategy in
\end{tabular}

Problem-Based Learning In An Online Reading Course... 
194 | Jurnal Pendidikan dan Kewirausahaan Vol. 9 No. 12021

\begin{tabular}{|c|c|}
\hline thinking skills & $\begin{array}{l}\text { teaching is quite appropriate. Even } \\
\text { though at the beginning of the } \\
\text { learning it caused anxiety, } \\
\text { moreover I was not used to } \\
\text { experiencing it implementation } \\
\text { PBL learning process. But so far } \\
\text { the activities provided by the } \\
\text { lecturers have allowed me to } \\
\text { develop my critical thinking skills } \\
\text { [Learning objective]. In my } \\
\text { opinion, the PBL strategy given by } \\
\text { the lecturer is quite good and } \\
\text { interestingly enough by adapting to } \\
\text { a pandemic. Personally I have } \\
\text { become more active in learning, my } \\
\text { critical thinking skills are } \\
\text { stimulated, can find out about } \\
\text { problems around and the latest } \\
\text { information and also improve my } \\
\text { problem solving skills. But there is } \\
\text { one internal obstacle for me which } \\
\text { is time management [Challenges]. }\end{array}$ \\
\hline $\begin{array}{l}\text { Document analysis } \\
\text { support }\end{array}$ & $\begin{array}{l}\text { I do not have the official English } \\
\text { curriculum, so this depends on } \\
\text { lecturer, what I should teach in } \\
\text { class. The syllabus of Critical } \\
\text { Reading Course only consists of } \\
\text { some components; course } \\
\text { description, course competency } \\
\text { standardization, and subject matter } \\
\text { of the course. Thus, I have to think } \\
\text { to find the right learning topics for }\end{array}$ \\
\hline
\end{tabular}

Problem-Based Learning In An Online Reading Course.... 


\begin{abstract}
my students. Especially giving the topic of material how to think critically [Support]

The topic of discussion such as understands about neurolinguistics, how to think critically, and analyze the text in the form of articles, analyze a news, and short film
\end{abstract} [Support].

The portraits of the Implementation of Problem Based Learning in online learningand teaching in reading course during covid-19 pandemic obtained through the students and lecturer perceptions. The following show how the students and lecturer responded.

\title{
a) Students' Perceptions in the Implementation of Problem-Based Learning in Online Learning in Reading Course During Covid-19 Pandemic
}

Students' have same and different perceptions of the implementation of Problem-Based Learning in an online learning in reading course during covid19 pandemic. The following show how the students' responded.

Students' Responded 1: Students' Perceptions in the implementation of Problem-Based Learning in online learning in reading course during covid19 pandemic

\section{Student \# 1}

I think it's same. Even though studying via online, the material is still conveyed well and with the implementation of PBL in my opinion the lecturer's strategy in teaching is quite appropriate. But there are obstacles when studying online such as lost signals, if many tasks such as analyzing videos, uploading videos, or zooming meetings, it takes out a lot of internet. Even though at the beginning of the learning it caused anxiety, moreover I was not used to experiencing it implementation PBL learning process. But so far the activities provided by the lecturer have allowed me to develop my critical thinking skills (Student \#1, In-depth Interview, 30 April 2021, Researcher Translation). 


\section{Student \# 2}

As far as I remember the lecturer did not provide knowledge and PBL skills before learning activities. So sometimes I find it difficult because my lecturer are quite slow in responding. So I less motivation or direction from my lecturer, and also I have obstacle which is time management and sometimes signal is lost during the learning process (Student \#2, In-depth Interview, 30 April 2021, Researcher Translation).

\section{Student \# 3}

In my personally I think that the implementation of PBL is enough to motivate me to learn but there is still a lack of skills and knowledge in the implementation of learning with PBL strategy. But, for me with online learning in reading course is less effective when compared to face to face, because if I study alone I am less enthusiastic in solving problems. Because previously I could work in groups with my friends directly, but now I can't anymore, but there are no problems even though I can still understand every material well given by the lecturer. (Student \#3, In-depth Interview, 1 May 2021, Researcher Translation).

\section{Student \# 4}

In my opinion, the implementation of $P B L$ in an online learning in reading course doesn't really matter. Exactly, I become more creative in finding reading references independently and flexibility in learning time. But sometimes I still feel less confident in expressing my opinion. So if in the forum discussion I tend to be silent a lot because my confidence is still low (Student \#4, In-depth Interview, 2 May 2021, Researcher Translation).

\section{Student \# 5}

In the online learning with the implementation of PBL model used by the lecturer in the reading course is sufficient to promote my creativity in solving problems independently in some tasks given by the lecturer, it is enough to stimulate my critical thinking skills. And I feel that I have the skills to think and learn more focused because it is based on the problem.(Student \#5, In-depth Interview, 2 May 2021, Researcher Translation). 


\section{Student \# 6}

The experience felt during the pandemic in the implementation of $P B L$ model in an online reading course is quite make it easier for me to understand the material and be able to remember the material better, and for my critical thinking skills it's getting better. But on the other hand, this course is one of the skills that everyone must have and when learning online it is rather difficult to implement (Student \#6, In-depth Interview, 4 May 2021, Researcher Translation).

Drawing on the interview data, students' have same and different perceptions of the implementation of Problem-Based Learning in online learning in reading course during covid-19 pandemic.The similarity is with the implementation of Problem-Based Learning in online reading course they feel that the learning material is easier to remember and understand and another similarity is that sometimes there are problems with signal during the learning process. The differences in the students' perceptions is that some students feel motivated in learning with the implementation of PBL and also they feel are still lacking enthusiasm to solve some of the problems given by the lecturer, but there are also those who feel motivated to solve problems and other differences they are still not satisfied with the implementation of PBL in online learning, but there are also those who feel that there is no problem with the implementation of PBL in the online reading course.

Besides that, it was found that students' perceptions in the implementation of Problem-Based Learning in online learning in reading course during covid-19 pandemic is there are some obstacles in undergoing online PBL that can be divided into 2 categories, namely: internal obstacle (which come from within the student), external obstacle (which from outside the student). Internal obstacles come from traits such as less of enthusiasm in solving problems because of continuous independent learning, knowledge in undergoing the PBL model is still less, and still less of confidence in expressing opinions. Meanwhile, external obstacles such as lost signal when learning activities take place and are also associated with quite a lot of internet costs. 


\section{b) Lecturer Perceptions in the Implementation of Problem-Based Learning in Online Teaching in Reading Course During Covid-19 Pandemic}

Lecturer have a conception of in the implementation of Problem-Based Learning in online teaching in reading course during covid-19 pandemic. The following show how the lecturer responded.

\section{Lecturer}

In the teaching online reading course toward the implementation of Problem-Based Learning model during pandemic, first in online teaching I applied the synchronous (via zoom meeting and google meet) and asynchronous (WhatsApp group) methods and the obstacle during online teaching is if the lost network. Then, for the implementation of PBL is quite challenging to select the material that I should to use in an online reading course. And determining the problem in $P B L$ is sometimes difficult, usually if it is too difficult for students with low abilities to be confused about what to do, they tend to be passive. On the other hand, if I given an easy problem for students with high ability, they feel less challenged with the given problem. But, with the results of implementing the PBL model in this online reading course, I am quite satisfied with the student learning outcomes. They are quite active and their thinking skills can be seen with the tasks that I given, such as analyzing scientific journal texts and others (Lecturer, In-depth Interview, 2 May 2021, Researcher Translation).

The researcher found that lecturer perception in the implementation of Problem-Based Learning in online teaching in reading course during covid-19 pandemic that he gets some challenges and obstacles when online teaching during pandemic with the implementation of PBL. Some of the challenges in the implementing of PBL in online teaching are to select the material that he should use in the online reading course and also to control students in solving problems given by the lecturer.

Further, based on the research data showed that at the stage of lesson planning lecturer experience the difficulty of determining the good problem to discuss students independently. Students with low abilities they tend to be passive 
in online learning activities. The problems presented by the lecturer are considered challenging for students with high ability, but students with low abilities feel unable to do anything. The facts above are actually in accordance with what was revealed by Widjajanti (2011) that PBL is learning based on the problem, so that the selection of the problem is very important thing and not easy. Problems in PBL should be selected in such a way as to challenge students' interest in solving them, connecting with previous experiences and learning, and requires cooperation and strategy to solve it. Further, Dabbagh (2019) define Problem-Based Learning is a pedagogical model that engages learners in a complex problem-solving activity in which the problem drives all learning and no formal prior knowledge is assumed in the content area for which the problem is intended.

The conditions above can be said that the selection of problem from real problems oriented in student life should be able to help students construct their knowledge through their surroundings and their critical thinking skills, but some students just not used to the real problem. They are used to finishing problems after there are examples of questions from the lecturer. And also when in terms of social interaction in the learning process of the implementation of online PBL is sometimes not as expected.

In particular, the lecturer has an obstacles when positioning the role as a facilitator, guiding, exploring understanding on a deeper level, supporting student initiatives is not easy. As Arends (2008) stated that PBL has several stages including: 1) Providing orientation about problem to students; 2) Organizing students for researching; 3) Assist in self-investigation and groups; 4) Develop and present work or report; 5) Analyze and evaluate problem solving process.

Based on the results this condition showed that the learning carried out is not in accordance of the third and fifth stages of PBL implementation, the third stage namely the lecturer assist independent investigations or group, which lecturer should help students to get information, find explanations and appropriate solutions, but based on the interview that lecturer did not do that stage. And the fifth stage is analyze or evaluate the problem solving process. Where the lecturer should help students to get the right information, implement experiment and look 
for explanations and solutions and in which the lecturer helps students to reflect on their, but based on the results the lecturer did not analyze or evaluate students on the procss of solving the problems.

\section{Critical Thinking Skills in the Implementation of Problem-Based Learning in Online Reading Course}

The second theme selected from the interview data was critical thinking skills in the implementation of Problem-Based Learning in online reading course. In implementing the Problem-Based Learning in online reading course to stimulate critical thinkng skills, the lecturer and students responded are various as reflected in the following interview data. The following show how the students and lecturer responded.

a) Students' Perceptions on Critical Thinking Skills in the Implementation of

\section{Problem-Based Learning in Online Reading Course}

Students' Responded 2: Critical Thinking Skills in the Implementation of Problem-Based Learning in Online Reading Course

\section{Student \# 1}

After implementing the PBL model, I was able to understand, analyze and evaluate information better. But the process takes need more effort for me (Student \#1, In-depth Interview, 30 April 2021, Researcher Translation).

\section{Student \# 2}

So far, what the lecturer strategy given my critical thinking level have gotten better, especially according to the subject is critical reading, where we are required to read critically from informations or texts such as journals (Student \#2, In-depth Interview, 30 April 2021, Researcher Translation).

\section{Student \# 3}

I feel my critical thinking skills are still average, haven't improved significantly after implementation of the PBL model. It's just because most of the activities are analyzing the text so I try to think more deeply. But sometimes I am more active during the learning processand I have been more motivated to learn (Student \#3, In-depth Interview, 1 May 2021, Researcher Translation). 
Drawing on the interview data, it was found that students' critical thinking skills in the implementation of Problem Based-Learning is quite appropriate to promote their critical thinking level and they are trained to solve problems using their critical thinking even though with more effort. As far as the importance of critical thinking skills, students participants agreed about it. As it represents an innovative way of learning model, promote self-directing learning and helps in improving problem solving skills an appropriate for the learners. As Kartal (2014) stated that the goal of PBL is to apply the skill of critical thinking, problemsolving, and content knowledge to solving real-world problems and issues. Further, as Ragilia (2018) stated that PBL supports students' thinking skills to a higher level, especially their critical thinking skills.

Besides that, based on the students' responses that the critical thinking skills in the implementation of Problem-Based Learning in online reading course they think that actually PBL is one of the learning strategies that can improve their critical thinking skills. One of concept of critical thinking skills is from Facione (2019) define that critical thinking skills is self-regulation in deciding (judging) something produce interpretations, analyzes, evaluations, and inferences, as well as presentations using a proof, concept, methodology, criteria, or judgment contextual basis on which decisions are made. Based on the results critical thinking skills in the implementation of Problem-Based Learning is not in accordance with the concept of critical thinking skills, which in the implementation of PBL the lecturer has not carried out an evaluation to students which to trigger students critical thinking skills. Lecturer should focus attention to the frequency at which students are using critical thinking throughout their course, which could increase students performance in this particular area, especially if critical thinking is an explicit outcome within the implementation of ProblemBased Learning in online reading course.

\section{b) Lecturer Perceptions on Critical Thinking Skills in the Implementation of Problem-Based Learning in Online Reading Course}

Lecturer Responded 2: Critical Thinking Skills in the Implementation of Problem-Based Learning in Online Reading Course 


\section{Lecturer}

In my opinion one of the learning strategies that can prepare students is a problem based learning (PBL). Students can find various alternative solutions if students have critical thinking skills. I think PBL is one of the learning strategies that can empower critical thinking skills that include interpretation, analysis, evaluation, and explanation.Besides that, in applying the Problem Based Learning in an online reading course, I combine the 4 pillars of neurolinguistics to produce more meaningful and creative material and also to promote students' critical thinking skills. Although in the online reading class at that time there were still many students who were not confident in expressing their opinions, but there were some students who were enthusiastic in the learning process and already had good critical thinking skills (Lecturer, In-depth Interview, 2 May 2021, Researcher Translation).

The lecturer reported that critical thinking is a required skill in learning and in this century it is necessary to design an environment and process of active learning and self directed learning. The lecturer said that the implementation of the PBL model was quite satisfactory for him, although the results were not yet maximal. But the students are quite able to analyze some texts well and I think they are able to solve the problems well. Besides, in the implementation of PBL he has applied in combination with the 4 pillars of neurolinguistics which makes learning more memorable and also to stimulate students' critical thinking skills. As Dabbagh (2019) suggests that critical thinking is one of the seven key domains that are defining desirable higher education student learning outcomes and is defined as thinking critically, solving problems, synthesizing information, and sense-making.

Further, lecturer said that the implementation of learning activities by using Problem-Based Learning model is one of good strategy because they could understand more about the materials and encourage them to solve problems independently or in groups. As Yamin (2013) stated that the purpose of ProblemBased Learning is to increase intrinsic motivations and skills in a problem 
solving, a collaboration, and a self-directed lifelong learning. These findings are not surprising.

\section{The Activities of Online Reading Course in the Implementation of Problem-Based Learning to Stimulate Critical Thinking Skills}

The third theme is the activities of online reading course in the implementation of Problem-Based Learning to stimulate critical thinking skills. The following are the responses from the students and lecturer participants:

Students' and Lecturer Responded 3: The Activities of Online Reading Course in the Implementation of Problem-Based Learning

\section{Student \# 1}

The activities such as understanding the article and re-explaining it in own language, analyze the moral message from the short film entitled Spirit: Stallion of the Cimarron-Canyon Chase and Leap of Faith and then present it in the form of a video. For me, it is one of the activity that can improve my critical thinking skills. The next activity or task, namely analyzing the content of the news. All of these activities are carried out independently and that is for me triggered my critical thinking level, make me remember the material better and trained me to solve problems (Student \#1, In-depth Interview, 30 April 2021, Researcher Translation).

\section{Student \# 3}

The activity given by the lecturer are read journals, analyze news and analyze the message of the film. I think there is a benefit of this assignment is that it quite triggers me to think more critically. Although sometimes it feels difficult and boring because many activities that must be completed independently are not available in groups, so in my opinion there must be challenging and interesting activities to be completed as a group. (Student \#3, In-depth Interview, 1 May 2021, Researcher Translation).

\section{Student \# 4}

The activity provided is in the form of journal scientific articles on the theme of reading, reading news and analyzing it, watching short films and then analyzing the moral messages. These activities are carried out by simply doing it in the form of a word file and some are presented directly 
via video and sometimes some are presented directly at the zoom meeting. But I think the lecturer still hasn't given directions to solve the problem properly (Student \#4, In-depth Interview, 2 May 2021, Researcher Translation).

\section{Student \# 6}

Analyzing online news, for example expressing opinions on Indonesian ministerial resufle, as well as analyzing videos. For assignments from journals and books, namely analyzing the content of article and making power points on critical reading and explaining in video. I think from these activities I feel enjoy and I don't feel anything bad for me (Student \#6, In-depth Interview, 4 May 2021, Researcher Translation).

\section{Lecturer}

The activities that are read and analyze scientific articles on the theme of reading, analyzing the moral message from a short film, reading the news and then presenting it in their own language, and provide a specific case then students provide critical thinking, and I provide mini research to train students in solving problems and their critical thinking skills (Lecturer, Indepth Interview, 2 May 2021, Researcher Translation).

The data showed that the activities are: 1) analyzing of scientific articles or journals, 2) analyzing short films, 3) analyzing some of online article, and 4) analyzing online news. From the interview data that the students feel their critical thinking is quite stimulated, their critical reading skills also increased after being given several articles which for them had a lot of unfamiliar vocabulary, it means students get more understanding about the new knowledge in the content of the article. But on the other hand they still feel less challenged and sometimes feels bored with the activities given by the lecturer because they want an activity where they can solve problems and discuss in groups.

From conditions above, it can be said that the learning has not accordance in one of the characteristics of PBL, namely the problem challenges students' current knowledge, attitudes and competencies. As Tan (2002) suggests that PBL approaches in a curriculum usually include the following characteristics: (1) The problem is the main point of learning, (2) the problem is usually used a real-world 
problem that appears unstructured, it is meant to be as authentic as possible, (3) the problem of PBL promotes the solution by taking into consideration knowledge from several subject and topics, (4) the problem challenges students' current knowledge, attitudes and competencies, the calling for identification of learning needs and new areas of learning, (5) self-directed learning is primary. Thus students assume major responsibility for the acquisition of information and knowledge, (4) development of investigation and problem-solving skills is as important as content knowledge to solve the problem. The PBL tutor thus facilitates and traines through questioning and cognitive coaching, and (5) PBL also includes with an evaluation and review of the learner's experience and the learning processes.

\section{The Design of Syllabus Used in Reading Course inthe Implementation of \\ Problem-Based Learning}

In the design of syllabus and learning materials in reading course in the implementation of Problem-Based Learning, the lecturer design such simple and concise documents that truly meet the learning needs of their students. The design of syllabus can be seen below.

\section{a) Course Description}

While fueloping the skills introduced and developed in Critical Reading (e.g. getting general and specific information from the text, getting the main ideas and detailed information from the text, deducing the meaning of words, phrases and sentences based on the context, and explaining relations between parts of the text through grammatical cohesive devices, and developing the skills of inferencing, analyzing, and synthesizing, and speed reading, evaluating texts or reading critically. Critical Reading also aims at the improve students' criticalthinking skills in reading activities which include (1) before reading activities are carried out, (2) at the time reading activity takes place, and (3) after the readingactivity ends.The skills of summarizing and evaluating texts are developed. While individual performances are noted, pair and group work should be encouraged. Assessment of success is based on portfolios and mid term as well as final examinations. 


\section{b) Course Competency Standardization}

Upon the completion of the course, the students are expected to:

(1) have gained vocabulary mastery of approximately 7,500 words and knowledge of grammatical structures, text organization, and cultural understanding required to comprehend various types of texts

(2) acquire a good comprehension of various reading texts and a good understanding of critical reading strategies

(3) analyze and evaluate texts

(4) he ahle to identifv arouments that are nro contra and refute

c) Subject Matter Of The Course

\begin{tabular}{cl}
\hline No. & \multicolumn{1}{c}{ Details of the Subject } \\
\hline 1. & Analyzing of scientific articles or journals \\
\hline 2. & Analyzing short films \\
\hline 3. & Analyzing some of online article \\
\hline 4. & Analyzing online news \\
\hline
\end{tabular}

Based on the design syllabus above, the data revealed that the lecturer did not provide a complete syllabus as listed learning resources. Besides that, the syllabus does not consist of the code of the subject, prerequisite, CEFR Level, and information about the mid-term and final exam. The syllabus did not state the description about the subject but at the syllabus it was stated briefly the focus of skill subject Critical Reading Course and focus on how to think critically.

\section{CONCLUSION}

Based on the analysis of the research findings and the discussion, the researcher concluded that the implementation of Problem-Based Learning in an online reading course had some positive impact and some obstacles. The positive impact it was found that Problem-Based Learning is quite appropriate to promote students critical thinking skills and solve problems using their critical thinking even though with more effort, the students can study more focused, students learn to understand and analyze not memorizing so that it triggers the activity to seek information independently and have information search skills. 
Besides that, the findings of obstacles reveal that students had some obstacles in undergoing online PBL that can be divided into 2 categories, namely: internal obstacle (which come from within the student), external obstacle (which from outside the student). Internal obstacles come from traits such as less of enthusiasm in solving problems because of continuous independent learning, knowledge in undergoing the PBL model is still less, and still less of confidence in expressing opinions. Meanwhile, external obstacles such as lost signal when learning activities take place and are also associated with quite a lot of internet costs. Further, the lecturer brings about such obstacles as difficulty of determining the good problem to stimulate development students intellectual and critical thinking skills, and lecturer are not easy to position self as a facilitator, guiding, exploring deeper understanding, and supporting students initiative.

\section{REFERENCES}

Arends. R. (2008). Learning to teach ( $7^{\text {th }}$ ed.). Belajar untuk Mengajar (Terjemahan Helly Prajitno Soetjipto dan Sri Mulyantini Soetjipto pada Tahun 2008). Yogyakarta: Pustaka Pelajar.

Dabbagh, N. (2019). Effects of PBL on Critical Thinking Skills. The Wiley Handbook of Problem- Based Learning, First Edition, 135-156. John Wiley \& Sons, Inc. https://doi.org/10.1002/9781119173243.ch6

Facione, PA. (2010). Critical Thinking: What It Is and Why It Counts. Insight $\begin{array}{llll}\text { Assesment. } & \text { 1-24. } & \text { Retrieved }\end{array}$ https://www.researchgate.net/publication/251303244

Fakhriyah, F. (2014). Penerapan Problem Based Learning dalam Upaya Mengembangkan Kemampuan Berpikir Kritis Mahasiswa. Jurnal Pendidikan IPA Indonesia, 95-101. Retrieved fromhttp://journal.unnes.ac.id/nju/index.php/ipii

Gay, L. R. (2012). Educational research. New York: PEARSON.

Kartal, T. A. (2014). The Effect of problem-Based Learning Approach on Conceptual Understanding in Teaching of Magnetism Topics. International journal of Physics and Chemistry Education, Vol. 6 No. 2. 
Kumar, R., \& Refaei, B. (2017). Problem-based learning pedagogy fosters students'critical thinking about writing. Interdisciplinary Journal of Problem-Based Learning, (2), 11. https://doi.org/10.7771/1541-5015.1670

Lin. (2017). Impacts of the Problem-based Learning Pedagogy on English Learners' Reading Comprehension, Strategy Use, and Active Learning Attitudes. Journal of Education and Training Studies, Vol. 5, No. 6.https://doi.org/10.11114/jets.v5i6.2320

Lin. (2017). Integrating the Problem- Based Learning Approach Into Web- Based English Reading Course. Journal of Education Computing, 129.https://doi.org/10.1177/0735633117705960

Malahayati, N. E. (2018). Application of Cooperative Learning Models Integrated Reading And Composition (CIRC) Integrated Problem Based Learning (PBL) to Improve Problem Solving Ability and Ability Thinking Critical Students of the V Semester of Academic Year 2016/2017 Islamic University Balitar. KONSTRUKTIVISME, Vol. 10, No. 1. Retrieved from http://konstruktivisme.unisbablitar.ejournal.web.id

Nassaji, H. (2015). Qualitative and descriptive research: Data type versus data analysis. Language Teaching Research, 19(2), 129-132. https://doi.org/10.1177/1362168815572747

Ragilia, N., Ambarita, A., Rusminto, N, O., (2018). Development of Problem Based Learning Model Learner Worksheet To Improve Critical Thinking Ability. IOSR Journal of Research \& Method in Education, PP 65-72. https://doi.org/10.9790/7388-0801046572

Sulaiman, A. \& Azizah, S. (2020). Problem-Based Learning To Improve Critical Thinking Ability In Indonesia: A Systematic Literature Review. Jurnal Pedagogik, Vol. 07 No. 01. https://doi.org/10.33650/pjp.v7i1.792

Suherni, S. (2021). Peningkatan Hasil Belajar Bahasa Inggris Melalui Implementasi Model Pembelajaran Murder Pada Siswa Kelas Ix Smp N 7 Mataram, Nusa Tenggara Barat. Jurnal Pendidikan Dan Kewirausahaan, 8(2), 118-127. https://doi.org/10.47668/pkwu.v8i2.109

Tan, O. (2002). Problem-based learning: More problems for teaching education. National Institute of Education, 43-55. 
209 | Jurnal Pendidikan dan Kewirausahaan Vol. 9 No. 12021

Thomas, I. (2010). Critical Thinking, Transformative Learning, Sustainable Education, and Problem-Based Learning in Universities. Journal of Transformative Education. $7-$ 245. https://doi.or/10.1177/1541344610385753

Widjajanti, D. B. \& Wahyudin. (2011). Mengembangkan kemampuan pemecahan masalah dan belief calon guru matematika melalui strategi perkuliahan kolaboratif. Cakrawala Pendidikan, 3(3), hlm, 401-415.

Yamin, S. (2013). The effect of Problem Based Learning on students' intrinsic motivation in the polytechnic's electrical engineering course. https://doi.or/10.1109/CHUSER.2011.6163841 